\title{
PENGARUH PENGGUNAAN BATTERY LIFE EXTENDER TECHNOLOGY TERHADAP TEMPERATUR CHARGING DAN BERAT ELEKTROLIT PADA YUASA LEAD ACID BATTERY TIPE LIQUID VENTED 12V 5Ah
}

\author{
Indra Angga Wibowo, C. Sudibyo, Basori \\ Program Studi Pendidikan Teknik Mesin, Jurusan Pendidikan Teknik Kejuruan, FKIP, UNS \\ Kampus UNS Pabelan JL. Ahmad Yani 200, Surakarta, Telp/Fax (0271) 718419 \\ Email : indraanggawibowo@gmail.com
}

\begin{abstract}
The purpose of this research: (1) To investigate battery temperature during charging using battery charger and electrolyte weight reduction in Yuasa lead acid battery $12 \mathrm{~V} 5$ Ah liquid vented type before giving battery life extender technology (Vitta- $Q$ battery vitamin). (2) To investigate battery temperature during charging using battery charger and electrolyte weight reduction in Yuasa lead acid battery $12 \mathrm{~V} 5 \mathrm{Ah}$ liquid vented type after giving Vitta-Q battery vitamin.

This research was used experimental method. The experiment was conducted at the Laboratory of Automotive Mechanical Engineering Education Program, the Laboratory of Mechanical Civil Education Program, JPTK FKIP UNS Surakarta and the Laboratory of Mathematics and Natural Sciences FMIPA UNS Surakarta which addressed at Ahmad Yani 200 Kartasura. The instruments which used to test were Delta DT.115K battery charger, Mettler Toledo digital balance, and Perkin Elmer UV/VIS Spectrometer. The research population were Yuasa $12 \mathrm{~V} 5 \mathrm{Ah}$ battery with code number YB5L-B and the research sample were 6 Yuasa $12 \mathrm{~V}$ $5 A h$ batteries with code number YB5L-B with lifetime of approximately 2 years or 20.000 miles. The comparative study descriptive investigation methode was used to analyse the data.

Based on this research can be concluded: (1) The measurement on Yuasa lead acid battery $12 \mathrm{~V} 5 \mathrm{Ah}$ liquid vented type before giving Vitta- $Q$ battery vitamin during charging using battery charger resulted the temperature $49^{\circ} \mathrm{C}$ and weight of electrolyte $209.5 \mathrm{gr}$ in $230.0 \mathrm{gr}$ electrolytes. (2) The measurement on Yuasa lead acid battery $12 \mathrm{~V} 5 \mathrm{Ah}$ liquid vented type after giving $2 \mathrm{ml}$ of Vitta - $Q$ battery vitamin per cell during charging using battery charger resulted the lowest temperature $40.3{ }^{\circ} \mathrm{C}$ and weight of electrolyte $216.4 \mathrm{gr}$ in $230.0 \mathrm{gr}$ electrolytes. (3) The measurement on Yuasa lead acid battery $12 \mathrm{~V} 5$ Ah liquid vented type after giving $3.5 \mathrm{ml}$ of Vitta $-Q$ battery vitamin per cell during charging using battery charger resulted the highest temperature $49.8^{\circ} \mathrm{C}$ and weight of electrolyte $208.1 \mathrm{gr}$ in $230.0 \mathrm{gr}$ electrolytes.
\end{abstract}

Keyword: battery life extender technology, charging temperature, weight of electrolytes, battery vitamin, lead acid battery.

\section{PENDAHULUAN}

Sumber energi listrik merupakan sumber yang paling banyak digunakan oleh manusia saat ini. Hal ini disebabkan karena listrik merupakan kebutuhan yang sangat vital dalam hidup manusia. Kebutuhan akan sumber energi listrik semakin lama semakin meningkat dan peningkatan ini harus di imbangi oleh penyediaan sumber energi listrik tersebut. Dari fakta yang ada saat ini bisa di lihat bagaimana listrik sangat berperan dalam seluruh bidang kehidupan. Sebagian besar alat yang di pakai peralatan industri menggunakan listrik sebagai sarana pengoperasiannya misal pada bidang otomotif, meliputi semua kendaraan dengan motor bakar. Sebagai contoh, mobil, sepeda motor, dan lori.

Pada kendaraan pembakaran dalam di sebut automotive battery atau starter battery, singkatnya SLI (Starting, Lighting, Ignition). Yang di maksud adalah lead acid battery dengan elektrolit cair, yang masih paling sering di gunakan sampai hari ini. (Jonny Dambrowski, 2009)

Baterai basah (lead acid battery) merupakan baterai yang dapat di isi ulang dan di gunakan berkali-kali. Baterai ini di buat dari anoda logam $\mathrm{PbO}_{2}$ dan katoda dari $\mathrm{Pb}$ dengan elektrolit asam sulfat encer. Jenis baterai ini banyak di gunakan oleh mobil dan motor. Selain harganya juga relatif murah di banding jenis yang lain, baterai $\mathrm{Pb}$ asam lebih lama pemakaiannya dari pada baterai kering untuk menerima beban listrik berubah (motor starter) dan beban konstan (lampu). (A. Grummy Wailanduw, Ladiono, 2010).

Baterai basah terdiri dari plat-plat timah $(\mathrm{PbO})$ yang di masukkan ke dalam larutan asam belerang $\left(\mathrm{H}_{2} \mathrm{SO}_{4}\right)$ dan kemudian plat-plat timah itu di hubungkan dengan tenaga listrik arus searah (DC) maka sifat-sifat itu akan segera berubah. Salah satu plat akan berwarna coklat tua, yang di sebabkan pembentukan periokside 
timah $\left(\mathrm{PbO}_{2}\right)$. Plat yang lain akan berwarna abuabu muda yang di sebabkan terbentuknya timah murni pada plat itu $(\mathrm{Pb})$.

Baterai basah yang beroperasi sepanjang waktu akan timbul sulfat kristal selama pengaliran. Dryout dan sulfation (bentuk berlebih dari timbal sulfat pada plat) adalah dua penyebab utama kegagalan baterai dalam penyimpanan sistem tenaga. (Kurt Salloux, 2007). Pembentukan sulfat bisa berakibat oleh perawatan yang salah, antara faktor-faktor lain ini menyebabkan perkembangan tahanan dalam baterai dan juga merintangi reaksi dalam baterai. Selanjutnya membuat proses pemuatan lebih sulit ketika baterai di isi karena akan menjadi sangat panas. Temperatur yang tinggi ini berdampak pada cepat berkurangnya larutan elektrolit karena menjadi uap. Berkurangnya larutan di setiap sel ini merupakan faktor utama kerusakan baterai. Panas yang di hasilkan dari reaksi kimia menimbulkan gas hydrogen dan penguapan yang menyebabkan elektrolit berkurang bila mana tidak terendamnya plat baterai oleh elektrolit mengakibatkan oksidasi oleh $\mathrm{O}_{2}$, terjadi korosi, dan sebagainya. Hal ini menyebabkan kondisi baterai kian menurun seiring dengan masa/usia pakai baterai basah pada kendaraan dan akhirnya membuat baterai benar-benar mati, tidak bisa di isi (recharge) lagi.

Maka dari itu perlu ada upaya dalam perawatan baterai untuk memperpanjang umur (life time) baterai. Kerusakan pada lead acid battery salah satunya di sebabkan timbulnya kerak $\mathrm{PbSO}_{4}$ pada permukaan elemen seiring penggunaan. Di mana kerak ini akan mempengaruhi kinerja baterai sehingga menyebabkan temperatur baterai tinggi, pengurangan elektrolit berlebih.

Salah satu zat yang dapat memperpanjang umur baterai adalah vitamin baterai. Vitamin baterai dapat mendukung dalam perawatan baterai. Penggunaan vitamin baterai dalam maintenance baterai diharapkan dapat memperpanjang umur pakai baterai. Baterai yang dapat bertahan tiga tahun biasanya menggunakan vitamin (di kutip dari Koran Republika selasa, 5 April 2011). Vitta-Q merupakan salah satu vitamin baterai yang berguna memperpanjang usia dan merekondisi baterai basah. Vitta-Q adalah cairan kimia yang ramah lingkungan, aman (non-hazardous), dan tidak mengandung asam yang dapat mengubah berat jenis elektrolit menjadi terlalu rendah. Penggunaannya pun cukup mudah dengan menambahkan larutan kimia ini kedalam elektrolit, per cell atau per baterai sesuai dengan kapasitas baterai. Formula kimia dari Vitta-Q akan merontokkan karang atau $\mathrm{PbSO}_{4}$ (timah sulfat) pada permukaan plat yang menutupi pori-pori plat, sehingga elektrolit dapat mengalir lancar saat baterai bereaksi, gelembung udara yang timbul kecil-kecil dan berlahan, panas yang di timbulkan menjadi lemah dan penguapan menjadi sedikit sekali. Lapisan kerak yang mengandung timah yang dapat menghantarkan listrik di dasar kotak baterai akan berkurang sehingga mengurangi resiko hubungan pendek antar pelat (di namakan hubungan pendek "dendritik") sehingga umur baterai akan bertambah.

\section{LANDASAN TEORI Baterai}

Baterai sekunder adalah baterai yang dapat di isi ulang. Baterai sekunder dapat di isi ulang karena reaksi kimia di dalam material aktifnya dapat diputar kembali. Baterai sekunder adalah baterai lead-acid, baterai $\mathrm{NiCd}$, baterai $\mathrm{NiMH}$, dll. Baterai lead acid dapat dikelompokkan menjadi Liquid Vented dan Sealed (VRLA Valve Regulated Lead Acid).

\section{Baterai Basah}

Saat ini jenis baterai yang paling umum di gunakan untuk penyimpanan energi adalah baterai basah.

Liquid vented (baterai dengan katup pengisian ulang cairan) adalah baterai yang terbuat dari lempengan positif dan negatif dari paduan timah yang di tempatkan dalam larutan elektrolit dan air asam sulfuric.

Saat baterai melepaskan muatan, material aktif pada elektroda bereaksi dengan elektrolit membentuk timbal sulfat $(\mathrm{PbSO} 4)$ dan air $(\mathrm{H} 2 \mathrm{O})$. Saat pengisian muatan, timbal sulfat berubah kembali menjadi timbal dioksida pada elektroda positif dan timbal pada elektroda negatif, dan ion sulfat $\left(\mathrm{SO}_{4}{ }^{2-}\right)$ kembali menjadi larutan elektrolit membentuk asam sulfat.

a. Proses pengaliran

$$
\mathrm{PbO}_{2}+2 \mathrm{H}_{2} \mathrm{SO}_{4}+\mathrm{Pb}=>\mathrm{PbSO}_{4}+2 \mathrm{H}_{2} \mathrm{O}+\mathrm{Pb}
$$

$\mathrm{SO}_{4}$

b. Proses pengisian

$\mathrm{PbSO}_{4}+2 \mathrm{H}_{2} \mathrm{O}+\mathrm{PbSO}_{4}=>\mathrm{PbO}_{2}+\mathrm{H}_{2} \mathrm{SO}_{4}+$ $\mathrm{Pb}$

\section{Prinsip Kerja Baterai}

Baterai bekerja berdasarkan reaksi kimia yaitu reaksi redoks yang terjadi baik selama pengisian maupun selama pengosongan. Reaksi kimia pada akumulator tersebut bersifat reversible, artinya reaksi 
kimia yang terjadi selama pengisian sangat berlawanan dengan reaksi yang terjadi pada saat pengosongan.

Selama pengisian terjadi pengubahan energi listrik ke energi kimia, dan sebaliknya pada saat pengosongan terjadi pengubahan energi kimia menjadi energi listrik. Ketika pengisian pada sumber energi listrik terjadi aliran listrik yaitu elektron mengalir dari katoda ke anoda. Dengan adanya aliran listrik tersebut, maka akan menimbulkan reaksi kimia (reaksi redoks) yang mengakibatkan terbebasnya zat-zat dalam baterai yaitu $\mathrm{PbSO}_{4}$ menjadi $\mathrm{Pb}, \mathrm{PO}_{2}$, ion $\mathrm{H}$ ${ }^{+}$, dan ion $\mathrm{SO}_{4}{ }^{2-}$.

Pada pengosongan, terjadi pengaliran listrik yaitu elektron mengalir dari $\mathrm{PbO}_{2}$ atau kutub positif (sebagai anoda) $\mathrm{ke} \mathrm{Pb}$ atau kutub negatif (sebagai katoda) sehingga adanya aliran tersebut mengakibatkan terjadinya reaksi kimia.

3. Faktor - Faktor yang Mempengaruhi Ketahanan Baterai

a. Pengaruh Temperatur

Temperatur yang tinggi di sebabkan karena terjadinya pensulfatan dan akibat pengisian berlebihan. Pensulfatan akibat dari self discharge di mana pada pelat timbul kristal timah sulfat halus dan lama-kelamaan akan mengeras. Tanda-tanda terjadinya pensulfatan adalah:

1) Terjadinya panas yang berlebihan.

2) Pembentukan gas yang cepat saat di beri arus pengisian yang besar.

b. Pengurangan Elektrolit yang Cepat

1) Over Charging

Pengisian berlebihan (over charging) menyebabkan elektrolit cepat berkurang karena penguapan berlebihan.

2) Self-Discharge

Besarnya self-discharge akan naik begitu temperatur dan berat jenis elektrolit dan kapasitas baterai tinggi.

3) Gassing

Energi listrik di isikan ke dalam sel dari sumber pengisi baterai DC tidak dapat lama di gunakan untuk perubahan kimia pada bahan elektrode aktif, dan oleh sebab itu menyebabkan penguraian elektrolit pada air (Daryanto, 2001 : 11).

4) Penguapan
Iklim tropis dan letak baterai dekat mesin menjadi faktor penguapan elektrolit yang tinggi. (Wan Ahmad Aziz, 2004)

\section{5) Korosi pada plat positif}

Korosi timah positif dan masa hidup baterai dapat di amati pada tingkat korosi sebanyak kadar keasaman dari penyusutan elektrolit.

\section{Vitamin Baterai Vitta-Q}

Vitta-Q adalah battery life extender technology. Berupa larutan kimia yang bekerja dengan sederhana, cairan Vitta-Q ini dapat merontokkan kerak sulfat yang menempel padat pada lempeng baterai, sehingga aliran elektron dapat kembali bekerja.

Berdasarkan hasil uji larutan menggunakan UV pada panjang gelombang 400-600 $\mathrm{nm}$ yang telah di lakukan di peroleh panjang gelombang (lamda) maks $=510$ yang menunjukkan adanya logam-logam transisi golongan 3 di mana logamlogam tersebut dapat mengendap dengan reagen $\left(\mathrm{NH}_{4}\right) 2 \mathrm{~S}$, yaitu golongan $3 \mathrm{~A}=\mathrm{Fe}, \mathrm{Al}, \mathrm{Cr}, \mathrm{Mn}$ yang dapat mengendap dengan reagen hidroksida dan golongan $3 \mathrm{~B}=\mathrm{Co}$, $\mathrm{Ni}$, $\mathrm{Zn}$ yang dapat mengendap dengan reagen garam sulfida. (Svehla. G, 1990: 204)

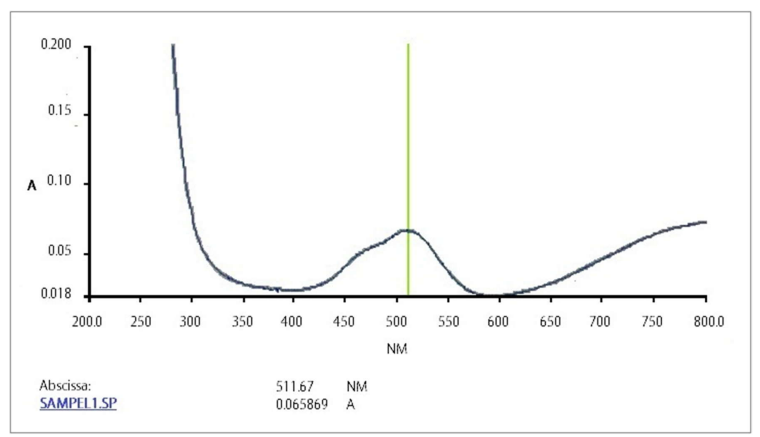

Gambar 1. Hasil spektrofotometri UV-Vis sampel

$$
\text { Vitta-Q }
$$

Logam $\mathrm{Fe}$ dan $\mathrm{Cr}$ mempunyai panjang gelombang maksimal $510 \mathrm{~nm}$. Di duga Vitta-Q mengandung $\mathrm{Cr}$ (Chromium), di mana merupakan logam tahan korosi karena reaksi dengan udara menghasilkan $\mathrm{Cr}_{2} \mathrm{O}_{3}$ yang bersifat nonpori. Berbeda dengan Fe (Iron) yang sangat reaktif secara kimiawi dan mudah terkorosi.

\section{METODE PENELITIAN}

Sampel dalam penelitian ini adalah 6 buah baterai Yuasa 12V 5Ah kode YB5L-B dengan masa pakai sekitar $20.000 \mathrm{~km}$ yang tanpa dan di 
berikan vitamin baterai Vitta-Q. Teknik pengambilan sampel dalam penelitian ini dengan menggunakan teknik sampel bertujuan/ purposive sample. Metode pengambilan data yang digunakan adalah metode dokumentasi dengan memotret hasil pengukuran dari digital thermometer dan neraca digital.

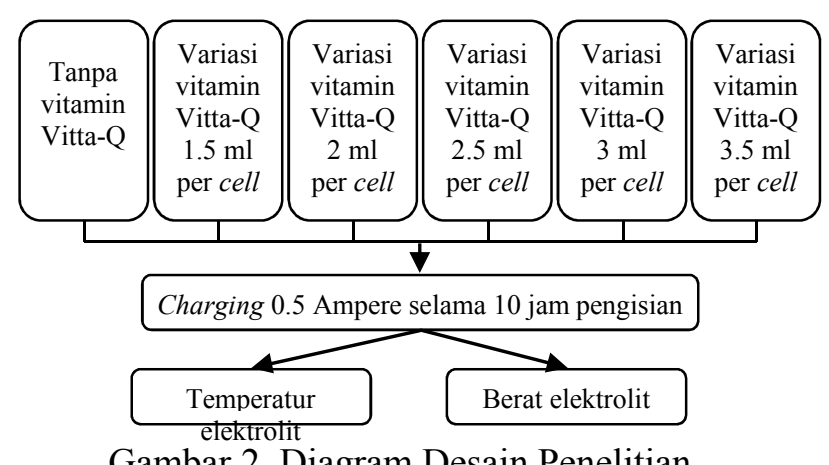

Gambar 2. Diagram Desain Penelitian

Eksperimen penelitian ini di awali dengan memberikan vitamin baterai Vitta-Q pada baterai. Variasi penggunaan vitamin baterai Vitta-Q per baterai sebagai berikut:

1. $9 \mathrm{ml}$ atau $1.5 \mathrm{ml}$ Vitta-Q per cell baterai.

2. $12 \mathrm{ml}$ atau $2 \mathrm{ml}$ Vitta-Q per cell baterai.

3. $15 \mathrm{ml}$ atau $2.5 \mathrm{ml}$ Vitta-Q per cell baterai.

4. $18 \mathrm{ml}$ atau $3 \mathrm{ml}$ Vitta-Q per cell baterai.

5. $21 \mathrm{ml}$ atau $3.5 \mathrm{ml}$ Vitta-Q per cell baterai.

Vitamin baterai Vitta-Q yang di gunakan dari distributor DK Chemindo - Jakarta. Alat ukur berupa Digital Thermometer Krisbow KW06-308 dan Neraca Digital Mettler Toledo.

\section{HASIL DAN PEMBAHASAN}

\section{Pembahasan Data Hasil Perhitungan Temperatur Baterai Selama Charging}

Dari hasil pengaruh penggunaan vitamin baterai Vitta-Q terhadap temperatur baterai selama charging pada Yuasa lead acid battery tipe liquid vented $12 \mathrm{~V} 5 \mathrm{Ah}$ dapat di bahas sebagai berikut:

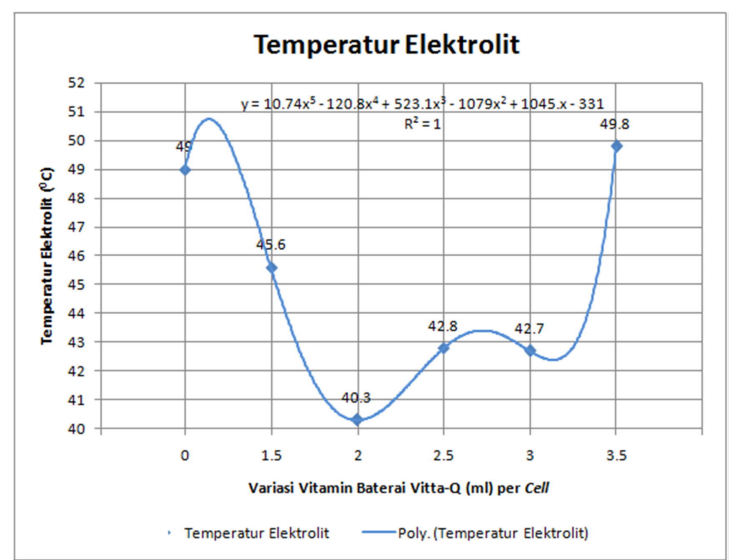

Gambar 3. Grafik Temperatur Baterai Selama Charging Tanpa dan dengan $1.5 \mathrm{ml}, 2 \mathrm{ml}, 2.5$ $\mathrm{ml}, 3 \mathrm{ml}, 3.5 \mathrm{ml}$ Vitta-Q per cell.

Pembahasan hasil pengukuran temperatur baterai selama charging dari setiap perlakuan sebagai berikut :

a. Berdasarkan Gambar 3. Baterai tanpa penggunaan vitamin baterai Vitta-Q mempunyai temperatur akhir $49.0{ }^{\circ} \mathrm{C}$.

Saat pengisian muatan, timbal sulfat berubah kembali menjadi timbal dioksida pada elektroda positif dan timbal pada elektroda negatif, dan ion sulfat $\left(\mathrm{SO}_{4}{ }^{2-}\right)$ kembali menjadi larutan elektrolit membentuk asam sulfat. Ion sulfat $\left(\mathrm{SO}_{4}{ }^{2-}\right)$ tidak dapat sepenuhnya kembali ke dalam elektrolit. Terikatnya ion sulfat $\left(\mathrm{SO}_{4}{ }^{2-}\right)$ pada timah di akibatkan $\mathrm{PbSO}_{4}$ tidak semuanya terlarut, sehingga kadar asam tidak dapat mencapai angka 1.265 pada kondisi fully charge.

Pori-pori pada plat akan tertutup sehingga elektrolit tidak bisa mengalir dengan lancar, kristal $\mathrm{PbSO}_{4}$ yang menghalangi perpindahan molekul asam sulfat mengakibatkan panas berlebih seiring kalor yang di hasilkan oleh besarnya arus pengisian. Sehingga temperatur naik seiring bertambahnya waktu pengisian.

b. Berdasarkan Gambar 3. Baterai dengan penggunaan vitamin baterai Vitta-Q sebanyak $1.5 \mathrm{ml}$ per cell mempunyai temperatur akhir $45.6^{\circ} \mathrm{C}$.

Saat pengisian muatan, timbal sulfat berubah kembali menjadi timbal dioksida pada elektroda positif dan timbal pada elektroda negatif, dan ion sulfat $\left(\mathrm{SO}_{4}{ }^{2-}\right)$ kembali menjadi larutan elektrolit membentuk asam sulfat. Ion sulfat $\left(\mathrm{SO}_{4}{ }^{2-}\right)$ tidak dapat sepenuhnya kembali ke dalam 
elektrolit. Terikatnya ion sulfat $\left(\mathrm{SO}_{4}{ }^{2-}\right)$ pada timah di akibatkan $\mathrm{PbSO}_{4}$ tidak semuanya terlarut, sehingga kadar asam tidak dapat mencapai angka 1.265 pada kondisi fully charge.

Pori-pori plat yang semula tertutup $\mathrm{PbSO}_{4}$ mulai tereduksi dengan pemberian $1.5 \mathrm{ml}$ Vitta-Q per sel. Logam $\mathrm{Cr}$ (Chromium) yang terkandung pada Vitta-Q dalam deret volta berada di sebelah kiri logam $\mathrm{Pb}$ sehingga logam $\mathrm{Cr}$ dapat mereduksi logam ion $\mathrm{Pb}$. Pergerakan elektrolit mulai dapat mengalir dengan lancar, tiap pasang ion hidrogen yang dekat dengan lempeng negatif bersatu dengan ion $\mathrm{SO}_{4}^{2-}$ pada lempeng negatif membentuk molekul asam sulfat.

Kristal $\mathrm{PbSO}_{4}$ yang semula menghalangi perpindahan molekul asam sulfat perlahan lancar sehingga temperatur lebih rendah dan naik perlahan sesuai kalor yang di hasilkan arus pengisian. Temperatur elektrolit pada baterai dengan $1.5 \mathrm{ml}$ vitamin baterai Vitta-Q lebih rendah sebesar $3.4{ }^{\circ} \mathrm{C}$ di banding baterai tanpa penggunaan vitamin baterai Vitta-Q.

c. Berdasarkan Gambar 3. Baterai dengan penggunaan vitamin baterai Vitta-Q sebanyak $2 \mathrm{ml}$ per cell mempunyai temperatur akhir $40.3{ }^{\circ} \mathrm{C}$.

Saat pengisian muatan, timbal sulfat berubah kembali menjadi timbal dioksida pada elektroda positif dan timbal pada elektroda negatif, dan ion sulfat $\left(\mathrm{SO}_{4}{ }^{2-}\right)$ kembali menjadi larutan elektrolit membentuk asam sulfat. Ion sulfat $\left(\mathrm{SO}_{4}{ }^{2-}\right)$ tidak dapat sepenuhnya kembali ke dalam elektrolit. Terikatnya ion sulfat $\left(\mathrm{SO}_{4}{ }^{2-}\right)$ pada timah di akibatkan $\mathrm{PbSO}_{4}$ tidak semuanya terlarut, sehingga kadar asam tidak dapat mencapai angka 1.265 pada kondisi fully charge.

Pori-pori plat yang semula tertutup $\mathrm{PbSO}_{4}$ mulai tereduksi dengan pemberian 2 ml Vitta-Q per sel. Logam Cr (Chromium) yang terkandung pada Vitta-Q dalam deret volta berada di sebelah kiri logam $\mathrm{Pb}$ sehingga logam $\mathrm{Cr}$ dapat mereduksi logam ion $\mathrm{Pb}$. Pergerakan elektrolit mulai dapat mengalir dengan lancar, tiap pasang ion hidrogen yang dekat dengan lempeng negatif bersatu dengan ion $\mathrm{SO}_{4}{ }^{2-}$ pada lempeng negatif membentuk molekul asam sulfat.
Kristal $\mathrm{PbSO}_{4}$ yang semula menghalangi perpindahan molekul asam sulfat perlahan lancar sehingga temperatur lebih rendah dan naik perlahan sesuai kalor yang di hasilkan arus pengisian. Temperatur elektrolit pada baterai dengan penggunaan $2 \mathrm{ml}$ vitamin baterai Vitta-Q per cell lebih rendah sebesar $5.3{ }^{\circ} \mathrm{C}$ di banding baterai dengan penggunaan $1.5 \mathrm{ml}$ vitamin baterai Vitta-Q per cell.

d. Berdasarkan Gambar 3. Baterai dengan penggunaan vitamin baterai Vitta-Q sebanyak $2.5 \mathrm{ml}$ per cell mempunyai temperatur akhir $42.8{ }^{\circ} \mathrm{C}$.

Saat pengisian muatan, timbal sulfat berubah kembali menjadi timbal dioksida pada elektroda positif dan timbal pada elektroda negatif, dan ion sulfat $\left(\mathrm{SO}_{4}{ }^{2-}\right)$ kembali menjadi larutan elektrolit membentuk asam sulfat. Pori-pori plat yang tertutup $\mathrm{PbSO}_{4}$ akan tereduksi oleh logam $\mathrm{Cr}$ (Chromium) yang terkandung pada Vitta-Q dalam deret volta berada di sebelah kiri logam $\mathrm{Pb}$ sehingga logam $\mathrm{Cr}$ dapat mereduksi logam ion $\mathrm{Pb}$. Namun pada pemberian Vitta-Q $2.5 \mathrm{ml}$ per cell ini nampak terjadi peningkatan temperatur kembali. Elektrolit yang di berikan Vitta-Q $2.5 \mathrm{ml}$ per cell mulai jenuh karena telah banyak ion yang senama. Pada keadaan jenuh telah terjadi kesetimbangan antara solut yang larut dan tak larut atau kecepatan pelarutan sama dengan kecepatan pengendapan.

Kristal $\mathrm{PbSO}_{4}$ tidak semuanya terlarut mengakibatkan terikatnya ion sulfat $\left(\mathrm{SO}_{4}{ }^{2-}\right)$, sehingga kadar asam tidak dapat mencapai angka 1.265 pada kondisi fully charge. Pori-pori pada plat masih tertutup sehingga elektrolit tidak bisa mengalir dengan lancar, kristal $\mathrm{PbSO}_{4}$ yang menghalangi perpindahan molekul asam sulfat mengakibatkan panas seiring kalor yang di hasilkan oleh besarnya arus pengisian. Temperatur elektrolit pada baterai dengan penggunaan $2.5 \mathrm{ml}$ vitamin baterai Vitta-Q per cell lebih tinggi sebesar $2.5{ }^{\circ} \mathrm{C}$ di banding baterai dengan penggunaan $2 \mathrm{ml}$ vitamin baterai Vitta-Q per cell.

e. Berdasarkan Gambar 3. Baterai dengan penggunaan vitamin baterai Vitta-Q sebanyak $3 \mathrm{ml}$ per cell mempunyai temperatur akhir $42.7{ }^{\circ} \mathrm{C}$. 
Saat pengisian muatan, timbal sulfat berubah kembali menjadi timbal dioksida pada elektroda positif dan timbal pada elektroda negatif, dan ion sulfat $\left(\mathrm{SO}_{4}{ }^{2-}\right)$ kembali menjadi larutan elektrolit membentuk asam sulfat. Pori-pori plat yang tertutup $\mathrm{PbSO}_{4}$ akan tereduksi oleh logam Cr (Chromium) yang terkandung pada Vitta-Q dalam deret volta berada di sebelah kiri logam $\mathrm{Pb}$ sehingga logam $\mathrm{Cr}$ dapat mereduksi logam ion $\mathrm{Pb}$. Namun pada pemberian Vitta-Q $3 \mathrm{ml}$ per cell ini nampak terjadi peningkatan temperatur kembali. Elektrolit yang di berikan Vitta-Q $3 \mathrm{ml}$ per cell mulai jenuh karena telah banyak ion yang senama. Pada keadaan jenuh telah terjadi kesetimbangan antara solut yang larut dan tak larut atau kecepatan pelarutan sama dengan kecepatan pengendapan.

Kristal $\mathrm{PbSO}_{4}$ tidak semuanya terlarut mengakibatkan terikatnya ion sulfat $\left(\mathrm{SO}_{4}{ }^{2-}\right)$, sehingga kadar asam tidak dapat mencapai angka 1.265 pada kondisi fully charge. Pori-pori pada plat masih tertutup sehingga elektrolit tidak bisa mengalir dengan lancar, kristal $\mathrm{PbSO}_{4}$ yang menghalangi perpindahan molekul asam sulfat mengakibatkan panas seiring kalor yang di hasilkan oleh besarnya arus pengisian. Temperatur elektrolit pada baterai dengan penggunaan $3 \mathrm{ml}$ vitamin baterai Vitta-Q per cell lebih rendah sebesar $0.1{ }^{\circ} \mathrm{C}$ di banding baterai dengan penggunaan $2.5 \mathrm{ml}$ vitamin baterai Vitta-Q per cell.

f. Berdasarkan Gambar 3. Baterai dengan penggunaan vitamin baterai Vitta-Q sebanyak $3.5 \mathrm{ml}$ per cell mempunyai temperatur akhir $49.8{ }^{\circ} \mathrm{C}$.

Saat pengisian muatan, timbal sulfat berubah kembali menjadi timbal dioksida pada elektroda positif dan timbal pada elektroda negatif, dan ion sulfat $\left(\mathrm{SO}_{4}{ }^{2-}\right)$ kembali menjadi larutan elektrolit membentuk asam sulfat. Pori-pori plat yang tertutup $\mathrm{PbSO}_{4}$ akan tereduksi oleh logam $\mathrm{Cr}$ (Chromium) yang terkandung pada Vitta-Q dalam deret volta berada di sebelah kiri logam $\mathrm{Pb}$ sehingga logam $\mathrm{Cr}$ dapat mereduksi logam ion $\mathrm{Pb}$. Namun pada pemberian Vitta-Q $3.5 \mathrm{ml}$ per cell ini nampak terjadi peningkatan temperatur kembali. Elektrolit yang di berikan Vitta-Q $3.5 \mathrm{ml}$ per cell mulai jenuh karena telah banyak ion yang senama. Pada keadaan jenuh telah terjadi kesetimbangan antara solut yang larut dan tak larut atau kecepatan pelarutan sama dengan kecepatan pengendapan.

Kristal $\mathrm{PbSO}_{4}$ tidak semuanya terlarut mengakibatkan terikatnya ion sulfat $\left(\mathrm{SO}_{4}{ }^{2-}\right)$, sehingga kadar asam tidak dapat mencapai angka 1.265 pada kondisi fully charge. Pori-pori pada plat masih tertutup sehingga elektrolit tidak bisa mengalir dengan lancar, kristal $\mathrm{PbSO}_{4}$ yang menghalangi perpindahan molekul asam sulfat mengakibatkan panas seiring kalor yang di hasilkan oleh besarnya arus pengisian. Temperatur elektrolit pada baterai dengan penggunaan $3.5 \mathrm{ml}$ vitamin baterai Vitta-Q per cell lebih tinggi sebesar $7.1{ }^{\circ} \mathrm{C}$ di banding baterai dengan penggunaan $3 \mathrm{ml}$ vitamin baterai Vitta-Q per cell.

\section{Pembahasan Data Hasil Perhitungan Berat Elektrolit Selama Charging}

Dari hasil pengaruh penggunaan vitamin baterai Vitta-Q terhadap berat elektrolit selama charging pada Yuasa lead acid battery tipe liquid vented $12 \mathrm{~V} 5 \mathrm{Ah}$ dapat di bahas sebagai berikut:

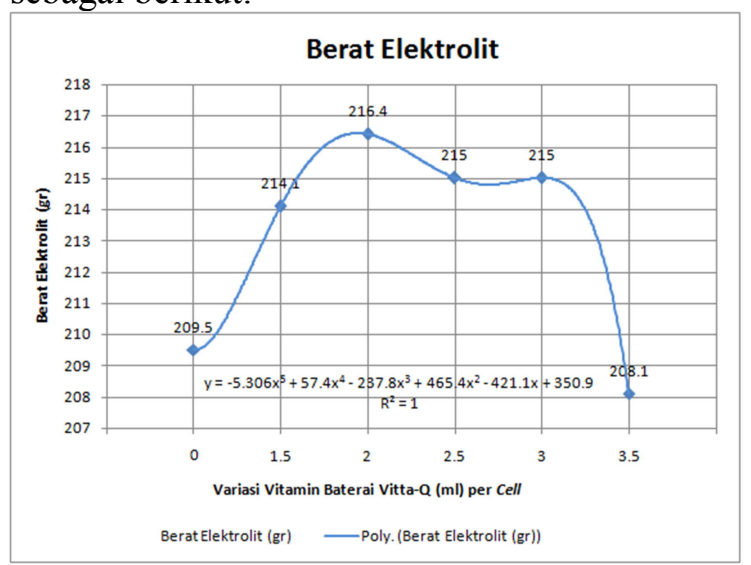

Gambar 4. Grafik Berat Elektrolit Baterai

Selama Charging Tanpa dan dengan $1.5 \mathrm{ml}, 2$ $\mathrm{ml}, 2.5 \mathrm{ml}, 3 \mathrm{ml}, 3.5 \mathrm{ml}$ Vitta-Q per cell.

Pembahasan hasil pengukuran temperatur baterai selama charging dari setiap perlakuan sebagai berikut :

a. Berdasarkan Gambar 4. Baterai tanpa penggunaan vitamin baterai Vitta-Q mempunyai berat elektrolit awal 230.0 gr dan berat elektrolit akhir 209.5 gr. Dengan melihat data tersebut, terjadi pengurangan berat elektrolit sebesar 20.5 gr. 
Saat pengisian muatan, timbal sulfat berubah kembali menjadi timbal dioksida pada elektroda positif dan timbal pada elektroda negatif, dan ion sulfat $\left(\mathrm{SO}_{4}{ }^{2-}\right)$ kembali menjadi larutan elektrolit membentuk asam sulfat. Ion sulfat $\left(\mathrm{SO}_{4}{ }^{2-}\right)$ tidak dapat sepenuhnya kembali ke dalam elektrolit. Terikatnya ion sulfat $\left(\mathrm{SO}_{4}{ }^{2-}\right)$ pada timah di akibatkan $\mathrm{PbSO}_{4}$ tidak semuanya terlarut, sehingga tersisa banyak $2 \mathrm{H}^{+}$yang bersatu dengan satu atom oksigen membentuk air $\left(\mathrm{H}_{2} \mathrm{O}\right)$ menyebabkan kadar asam tidak dapat mencapai angka 1.265 pada kondisi fully charge. Ketika temperatur meningkat seiring kalor yang di hasilkan oleh besarnya arus pengisian, energi kinetik molekul air ikut meningkat sehingga molekul air makin banyak yang berpindah ke lapis udara di atasnya menjadi uap air atau gas dengan simbol $\mathrm{H}_{2} \mathrm{O}_{(\mathrm{g})}$ dan massa elektrolit pun kian menurun.

b. Berdasarkan Gambar 4. Baterai dengan penggunaan vitamin baterai Vitta-Q sebanyak $1.5 \mathrm{ml}$ per cell mempunyai berat awal 230.0 gr dan mempunyai berat akhir 214.1 gr. Dengan membandingkan data tersebut, maka terjadi pengurangan berat elektrolit sebesar 15.9 gr.

Saat pengisian muatan, timbal sulfat berubah kembali menjadi timbal dioksida pada elektroda positif dan timbal pada elektroda negatif, dan ion sulfat $\left(\mathrm{SO}_{4}{ }^{2-}\right)$ kembali menjadi larutan elektrolit membentuk asam sulfat. Pori-pori plat yang semula tertutup $\mathrm{PbSO}_{4}$ tereduksi dengan pemberian $1.5 \mathrm{ml}$ Vitta-Q per sel. Logam Cr (Chromium) yang terkandung pada Vitta-Q dalam deret volta berada di sebelah kiri logam $\mathrm{Pb}$ sehingga logam $\mathrm{Cr}$ dapat mereduksi logam ion $\mathrm{Pb}$. Pergerakan elektrolit mulai dapat mengalir dengan lancar, tiap pasang ion hidrogen $\left(\mathrm{H}^{+}\right)$yang dekat dengan lempeng negatif bersatu dengan ion $\mathrm{SO}_{4}{ }^{2-}$ pada lempeng negatif membentuk molekul asam sulfat sehingga kadar asam meningkat.

Kristal $\mathrm{PbSO}_{4}$ yang semula menghalangi perpindahan molekul asam sulfat perlahan lancar sehingga temperatur lebih rendah dan naik perlahan sesuai tegangan yang di aplikasikan ke terminal selama pengisian. Temperatur yang lebih rendah dan naik perlahan seiring kalor yang di hasilkan oleh besarnya arus pengisian, energi kinetik molekul air lebih rendah sehingga molekul air makin sedikit yang berpindah ke lapis udara di atasnya menjadi uap air atau gas dengan simbol $\mathrm{H}_{2} \mathrm{O}_{(\mathrm{g})}$ dan penurunan massa elektrolit pun sedikit. Pengurangan berat elektrolit lebih rendah 4.6 gr di banding baterai tanpa vitamin baterai Vitta-Q.

c. Berdasarkan Gambar 4. Baterai dengan penggunaan vitamin baterai Vitta-Q sebanyak $2 \mathrm{ml}$ per cell mempunyai berat awal 230.0 gr dan mempunyai berat akhir 216.4 gr. Dengan membandingkan data tersebut, maka terjadi pengurangan berat elektrolit sebesar 13.6 gr.

Saat pengisian muatan, timbal sulfat berubah kembali menjadi timbal dioksida pada elektroda positif dan timbal pada elektroda negatif, dan ion sulfat $\left(\mathrm{SO}_{4}{ }^{2-}\right)$ kembali menjadi larutan elektrolit membentuk asam sulfat. Pori-pori plat yang semula tertutup $\mathrm{PbSO}_{4}$ tereduksi dengan pemberian $1.5 \mathrm{ml}$ Vitta-Q per sel. Logam Cr (Chromium) yang terkandung pada Vitta-Q dalam deret volta berada di sebelah kiri logam $\mathrm{Pb}$ sehingga logam $\mathrm{Cr}$ dapat mereduksi logam ion $\mathrm{Pb}$. Pergerakan elektrolit mulai dapat mengalir dengan lancar, tiap pasang ion hidrogen $\left(\mathrm{H}^{+}\right)$yang dekat dengan lempeng negatif bersatu dengan ion $\mathrm{SO}_{4}{ }^{2-}$ pada lempeng negatif membentuk molekul asam sulfat sehingga kadar asam meningkat.

Kristal $\mathrm{PbSO}_{4}$ yang semula menghalangi perpindahan molekul asam sulfat perlahan lancar sehingga temperatur lebih rendah dan naik perlahan sesuai kalor yang di hasilkan arus pengisian. Temperatur yang lebih rendah dan naik perlahan seiring kalor yang di hasilkan oleh besarnya arus pengisian, energi kinetik molekul air lebih rendah sehingga molekul air makin sedikit yang berpindah ke lapis udara di atasnya menjadi uap air atau gas dengan simbol $\mathrm{H}_{2} \mathrm{O}_{(\mathrm{g})}$ dan penurunan massa elektrolit pun sedikit. Pengurangan berat elektrolit lebih rendah 2.3 gr di banding baterai dengan $1.5 \mathrm{ml}$ vitamin baterai Vitta-Q per cell.

d. Berdasarkan Gambar 4. Baterai dengan penggunaan vitamin baterai Vitta-Q sebanyak $2.5 \mathrm{ml}$ per cell mempunyai berat awal 230.0 gr dan mempunyai berat akhir 215.0 gr. Dengan membandingkan data 
tersebut, maka terjadi pengurangan berat elektrolit sebesar 15 gr.

Saat pengisian muatan, timbal sulfat berubah kembali menjadi timbal dioksida pada elektroda positif dan timbal pada elektroda negatif, dan ion sulfat $\left(\mathrm{SO}_{4}{ }^{2-}\right)$ kembali menjadi larutan elektrolit membentuk asam sulfat. Pori-pori plat yang tertutup $\mathrm{PbSO}_{4}$ akan tereduksi oleh logam $\mathrm{Cr}$ (Chromium) yang terkandung pada Vitta-Q dalam deret volta berada di sebelah kiri logam $\mathrm{Pb}$ sehingga logam $\mathrm{Cr}$ dapat mereduksi logam ion $\mathrm{Pb}$. Namun pada pemberian Vitta-Q $2.5 \mathrm{ml}$ per cell ini nampak terjadi penurunan berat elektrolit kembali. Elektrolit yang di berikan Vitta-Q $2.5 \mathrm{ml}$ per cell mulai jenuh karena telah banyak ion yang senama. Pada keadaan jenuh telah terjadi kesetimbangan antara solut yang larut dan tak larut atau kecepatan pelarutan sama dengan kecepatan pengendapan.

Terikatnya ion sulfat $\left(\mathrm{SO}_{4}{ }^{2-}\right)$ pada timah di akibatkan $\mathrm{PbSO}_{4}$ tidak semuanya terlarut, sehingga tersisa banyak $2 \mathrm{H}^{+}$yang bersatu dengan satu atom oksigen membentuk air $\left(\mathrm{H}_{2} \mathrm{O}\right)$ menyebabkan kadar asam tidak dapat mencapai angka 1.265 pada kondisi fully charge. Ketika temperatur meningkat seiring kalor yang di hasilkan oleh besarnya arus pengisian, energi kinetik molekul air ikut meningkat sehingga molekul air makin banyak yang berpindah ke lapis udara di atasnya menjadi uap air atau gas dengan simbol $\mathrm{H}_{2} \mathrm{O}_{(\mathrm{g})}$ dan massa elektrolit pun kian menurun. Pengurangan berat elektrolit lebih tinggi 1.4 gr di banding baterai dengan $2 \mathrm{ml}$ vitamin baterai Vitta-Q per cell.

e. Berdasarkan Gambar 4. Baterai dengan penggunaan vitamin baterai Vitta-Q sebanyak $3 \mathrm{ml}$ per cell mempunyai berat awal 230.0 gr dan mempunyai berat akhir 215.0 gr. Dengan membandingkan data tersebut, maka terjadi pengurangan berat elektrolit sebesar $15 \mathrm{gr}$.

Saat pengisian muatan, timbal sulfat berubah kembali menjadi timbal dioksida pada elektroda positif dan timbal pada elektroda negatif, dan ion sulfat $\left(\mathrm{SO}_{4}{ }^{2-}\right)$ kembali menjadi larutan elektrolit membentuk asam sulfat. Pori-pori plat yang tertutup $\mathrm{PbSO}_{4}$ akan tereduksi oleh logam $\mathrm{Cr}$ (Chromium) yang terkandung pada Vitta-Q dalam deret volta berada di sebelah kiri logam $\mathrm{Pb}$ sehingga logam $\mathrm{Cr}$ dapat mereduksi logam ion $\mathrm{Pb}$. Namun pada pemberian Vitta-Q $3 \mathrm{ml}$ per cell ini nampak terjadi penurunan berat elektrolit kembali. Elektrolit yang di berikan Vitta-Q $3 \mathrm{ml}$ per cell mulai jenuh karena telah banyak ion yang senama. Pada keadaan jenuh telah terjadi kesetimbangan antara solut yang larut dan tak larut atau kecepatan pelarutan sama dengan kecepatan pengendapan.

Terikatnya ion sulfat $\left(\mathrm{SO}_{4}{ }^{2-}\right)$ pada timah di akibatkan $\mathrm{PbSO}_{4}$ tidak semuanya terlarut, sehingga tersisa banyak $2 \mathrm{H}^{+}$yang bersatu dengan satu atom oksigen membentuk air $\left(\mathrm{H}_{2} \mathrm{O}\right)$ menyebabkan kadar asam tidak dapat mencapai angka 1.265 pada kondisi fully charge. Ketika temperatur meningkat seiring kalor yang di hasilkan oleh besarnya arus pengisian, energi kinetik molekul air ikut meningkat sehingga molekul air makin banyak yang berpindah ke lapis udara di atasnya menjadi uap air atau gas dengan simbol $\mathrm{H}_{2} \mathrm{O}_{(\mathrm{g})}$ dan massa elektrolit pun kian menurun. Pengurangan berat elektrolit baterai sama dengan baterai $2.5 \mathrm{ml}$ vitamin baterai Vitta-Q per cell yaitu 15 gr.

f. Berdasarkan Gambar 4. Baterai dengan penggunaan vitamin baterai Vitta-Q sebanyak $3.5 \mathrm{ml}$ per cell mempunyai berat awal 230.0 gr dan mempunyai berat akhir 208.1 gr. Dengan membandingkan data tersebut, maka terjadi pengurangan berat elektrolit sebesar 21.9 gr.

Saat pengisian muatan, timbal sulfat berubah kembali menjadi timbal dioksida pada elektroda positif dan timbal pada elektroda negatif, dan ion sulfat $\left(\mathrm{SO}_{4}{ }^{2-}\right)$ kembali menjadi larutan elektrolit membentuk asam sulfat. Pori-pori plat yang tertutup $\mathrm{PbSO}_{4}$ akan tereduksi oleh logam $\mathrm{Cr}$ (Chromium) yang terkandung pada Vitta-Q dalam deret volta berada di sebelah kiri logam $\mathrm{Pb}$ sehingga logam $\mathrm{Cr}$ dapat mereduksi logam ion $\mathrm{Pb}$. Namun pada pemberian Vitta-Q $2.5 \mathrm{ml}$ per cell ini nampak terjadi penurunan berat elektrolit kembali. Elektrolit yang di berikan Vitta-Q $2.5 \mathrm{ml}$ per cell mulai jenuh karena telah banyak ion yang senama. Pada keadaan jenuh telah terjadi kesetimbangan antara solut yang larut dan tak larut atau 
kecepatan pelarutan sama dengan kecepatan pengendapan.

Terikatnya ion sulfat $\left(\mathrm{SO}_{4}{ }^{2-}\right)$ pada timah di akibatkan $\mathrm{PbSO}_{4}$ tidak semuanya terlarut, sehingga tersisa banyak $2 \mathrm{H}^{+}$yang bersatu dengan satu atom oksigen membentuk air $\left(\mathrm{H}_{2} \mathrm{O}\right)$ menyebabkan kadar asam tidak dapat mencapai angka 1.265 pada kondisi fully charge. Ketika temperatur meningkat seiring kalor yang di hasilkan oleh besarnya arus pengisian, energi kinetik molekul air ikut meningkat sehingga molekul air makin banyak yang berpindah ke lapis udara di atasnya menjadi uap air atau gas dengan simbol $\mathrm{H}_{2} \mathrm{O}_{(\mathrm{g})}$ dan massa elektrolit pun kian menurun. Pengurangan berat elektrolit lebih tinggi 6.9 gr di banding baterai dengan $3 \mathrm{ml}$ vitamin baterai Vitta-Q per cell.

\section{KESIMPULAN}

1. Hasil pengukuran pada Yuasa lead acid battery tipe liquid vented $12 \mathrm{~V} 5 \mathrm{Ah}$ selama charging menggunakan battery charger sebelum pemberian vitamin baterai Vitta-Q menghasilkan temperatur $49^{\circ} \mathrm{C}$ dan berat elektrolit 209.5 gr pada 230.0 gr elektrolit.

2. Hasil pengukuran pada Yuasa lead acid battery tipe liquid vented $12 \mathrm{~V} 5 \mathrm{Ah}$ selama charging menggunakan battery charger setelah pemberian $2 \mathrm{ml}$ vitamin baterai Vitta-Q per cell menghasilkan temperatur terendah yaitu $40.3{ }^{\circ} \mathrm{C}$ dan berat elektrolit 216.4 gr pada 230.0 gr elektrolit.

3. Hasil pengukuran pada Yuasa lead acid battery tipe liquid vented $12 \mathrm{~V} 5 \mathrm{Ah}$ selama charging menggunakan battery charger setelah pemberian $3.5 \mathrm{ml}$ vitamin baterai Vitta-Q per cell menghasilkan temperatur tertinggi yaitu $49.8{ }^{\circ} \mathrm{C}$ dan berat elektrolit 208.1 gr pada 230.0 gr elektrolit.

Anonim. (2013, 1 Maret). Statistic Motorcycle

\section{DAFTAR PUSTAKA}

Production Wholesales Domestic and Exports. Asosiasi Industri Sepeda Motor Indonesia. Di peroleh 13 Mei 2013, dari http://www.aisi.or.id/.

Arikunto, Suharsimi. (2010). Prosedur Penelitian Suatu Pendekatan Praktik. Jakarta: Rineka Cipta.

Botcolaboratories. (1991). Laboratory Test Report.

Botcolab Test Report. Di peroleh 4 April 2013, dari http://www.vittaq.com/pdf/botcolabs.pdf.

Catherino, H.A. (2004). Sulfation in Lead-Acid

Batteries. Journal of Power Sources 129 113-120. Di peroleh 17 April 2013, dari http://ac.els-cdn.com/S0378775303010681/1-s2.0-S0378775303010681-main.pdf.

Dambrowski, Jonny. (2009). About The Challenges

For Charging Techniques With Lead-Acid Batteries in The Automotive Industry. Deutronic Elektronik GmbH. Di peroleh 3 April 2013, dari http://deutronic.com/ladegeraete/deutroniclader_e.pdf.

Daryanto. (1987). Pengetahuan Teknik Listrik. Jakarta: Bina Aksara.

Daryanto. (2001). Pengetahuan Baterai Mobil.

Jakarta: Bina Aksara.

Daryanto. (2011a). Dasar-Dasar Kelistrikan Otomotif. Jakarta: Prestasi Pustaka.

Daryanto. (2011b). Sistem Kelistrikan Motor. Bandung: Satu Nusa.

Faqih, M. (2011, 5 April). Mengenal Accu awet dan

Panjang Umur. Republika. Di peroleh 18 Februari 2013, dari http://www.batteryglobal.com/artikel.php@kat=1\&id=2.html.

Grummy Wailanduw, A. Ladiono. (2010). Efektivitas Aki Basah dan aki Kering Terhadap Beban Listrik pada Kendaraan Bermotor. Surabaya: Program Strata Unesa.

Hafiz, W. A., (2004) Development of Asymmetric Polysulfone Membrane For The Application in Tropicalized Lead Acid Battery. Malaysia: Program Strata Universitas Teknologi Malaysia.

Hardi, Syam. (1983). Dasar-dasar Teknik Listrik Aliran Rata I. Jakarta: Bina Aksara.

Kiehne, H. A., (1989). Electrochemical Power Sources. Jerman: Expert Verlag.

Maylani, Yossi, (2003). Revitalisasi Akumulator Bekas. Semarang: Program Strata Unnes. 